\title{
Bazı fiğ türlerinin yem verim ve kalitesi üzerine farklı organik gübrelerin etkileri
}

\author{
The effects of different organic fertilizers on forage yield and quality of some vetch species
}

\author{
Ibrahim ERTEKIN ${ }^{1 \mathscr{C}}$ (D) , ibrahim ATIŞ $^{1}$ (D), Şaban YILMAZ ${ }^{1}$ (D) \\ ${ }^{1}$ Hatay Mustafa Kemal University, Faculty of Agriculture, Department of Field Crops, Antakya-Hatay, Turkey.
}

MAKALE BILGISI / ARTICLE INFO

Makale tarihçesi / Article history:

DOI: $\underline{10.37908 / m k u t b d .739805}$

Geliş tarihi /Received:19.05.2020

Kabul tarihi/Accepted:29.06.2020

\section{Keywords:}

Organic farming, Vetch species, Forage yield, Forage quality, Organic fertilizer.

\footnotetext{
Corresponding author: İbrahim ERTEKIN

$\triangle$ : ibrahimertekin@mku.edu.tr
}

\section{ÖZET / A BSTR A C T}




\section{GíRiş}

Baklagiller familyası çok kıymetli yem bitkilerini içerisinde barındırmaktadır. Baklagil yem bitkileri dünya çapında hayvan besleme amacıyla kullanılan en önemli bitki türlerinden birisidir. Bu bitkiler genelde doğal olarak çayır ve meralarda yetişmekte ve hayvanların temel kaba yem intiyacını karşılamaktadır (Ertekin ve Çakmakçı, 2020; Ertekin ve ark., 2018; Ertekin ve ark., 2017). Baklagil yem bitkilerinin besin değeri ve hayvanlar üzerindeki besleme etkisi oldukça yüksektir (Anil ve ark., 1998). Ayrıca baklagil bitkileri biyolojik azot fiksasyonunda önemli bir yere sahiptir (Anjum ve ark., 2006). Bu bitkiler içerisinde en yaygın değerlerdirilen cins ise fiğdir.

Organik tarım, sürdürülebilir tarımın bir parçası konumundadır. Organik tarım kapsamında son yıllarda faaliyetler sadece gelişmiş ülkelerde değil, aynı zamanda gelişmekte olan ülkelerde de hızla yaygınlaşmıştır. Bu durumun oluşmasında ki en önemli etken tüketicilerin kendi sağ|ıklarını ve çevreyi koruma istekleridir (Demiryürek, 2011). Tarımsal faaliyetler kapsamında kullanılan kimyasal girdiler önemli çevre ve sağlık problemelerine neden olmaktadır (Mert, 2017; Parlakay ve ark., 2015). Özellikle kimyasal azot kullanımı büyük çevre problemlerine neden olmaktadır. Fakat tarımsal gübrelemede farklı formlarda azot kullanımı bu riski azaltabilir (Akpınar ve ark., 2019). Bu yüzden son yıllarda ülkemizde organik tarıma olan ilgi giderek artmakta ve bu alanda yeni gelişmeler yaşanmaktadır. Özellikle bitki türlerinin kültüründe farklı yetiştirme teknikleri üzerinde birçok araştırma yapılmaktadır (Aygün ve ark., 2009). Geçmişte organik tarım Avrupa ve Amerika'da öncü kişiler tarafından ortaya çıkarılmıştır, fakat ülkemizde bu durum ihracata sunulan ürünlerde organik ürün talebinin ortaya çıkmasıyla gelişmiştir (Demiryürek, 2004). Son yıllarda ülkemiz de tüketim alışkanlıkları organik ürün yönünde değişmeye başlamıştır.

Türkiye'de organik ürün üretimi amacıyla 2017 verilerine göre 382.000 ha alanda tarımsal faaliyet yapılmış ve bu alandan yaklaşık 1.6 milyon ton organik ürün elde edilmiştir. Ayrıca bu üretim verilerinin yaklaşık 412.000 tonunu kaba yem üretimi kapsamaktadır. Organik kaba yem üretimi içerisinde yaklaşık 65.000 ton yaygın fiğ ve 267 ton Macar fiğ üretimi yapılmıştır. Organik tarımda tüylü fiğ üretimi istatistiklerde mevcut değildir. Ülkemizde organik hayvansal üretimde yer alan ruminant hayvan sayısı 100.000 civarındadır (Anonim, 2017). Ancak organik hayvan sayısı ile organik kaba yem üretimi ilişkilendirildiği zaman, hayvan sayısına üretilen kaba yem miktarının yetersiz kaldığı aşikardır.

Hayvan gübresi hem toprağın fiziksel ve biyolojik yapısını iyileştirmekte ve hem de çeşitli besin maddelerini toprağa kazandırmaktadır (Yolcu ve ark., 2010). Birçok araştırmada hayvan gübresinin bitkilerde verimi arttırdığı bildirilmiştir (Yolcu, 2011; Rotar ve ark., 2003; Karakurt, 2000).

Tarımsal faaliyetler kapsamında leonardit ve zeolit benzeri organik kaynaklı gübre kaynaklarının kullanımı verimin yanında sürdürülebilir ve organik tarım için her geçen gün yaygınlaşmaktadır (Gül ve ark., 2015). Zeolit doğal toprak Islah materyallerinden birisidir ve bu madde toprakta bulunan amonyum formundaki azotun nitrifikasyonunu azaltır (Işıldar, 1999). Böylece tarım alanlarında bitkilerin azottan faydalanmasını arttırır (Kurama ve ark., 1999) ve kimyasal gübre girdilerinden tasarruf edilebilir. Türk ve ark. (2003) yonca bitkisinde Yolcu (2011) yaygın fiğde zeolit organik gübresinin bitki verimini artı̇ırığını bildirmişlerdir.

Son zamanlarda zirai faaliyetler içerisinde kullanımı artan toprak düzenleyicilerden biriside leonardittir (Gül ve ark., 2015). Aslında leonardit bir hümik asit kaynağıdır ve bitkilerin besin maddelerinden yararlanmasını kolaylaştırarak bitki büyümesini güçlendirir ve hızlandırır (Pertuit ve ark., 2001). Uygun dozlarda kullanılan leonarditin bitkilerde faydalı olduğu çeşitli araştırıcılar tarafından bildirilmiştir (Yolcu ve ark., 2011; Ece ve ark., 2007; Kolsarıcı ve ark., 2005; Yetim, 1999).

Bu çalışma, organik hayvansal üretimde ihtiyaç duyulan kaba yemin karşılanmasında önemli bir potansiyele sahip olan bazı fiğ türlerinin ot verim ve kalitesi üzerine organik gübre olarak kullanılabilecek büyükbaş hayvan gübresi, zeolit ve leonarditin etkilerini belirlemek amacıyla yürütülmüştür.

\section{MATERYAL ve YÖNTEM}

\section{Materyal, denemenin planlanması ve ekim}

Bu çalışma 2017-2018 kışlık ürün ekim sezonunda Hatay Mustafa Kemal Üniversitesi Telkaliş Araştırma ve Uygulama arazisinde yürütülmüştür. Denemede yaygın fiğ (Vicia sativa L.), Macar fiği (Vicia pannonica Crantz.) ve tüylü fiğ (Vicia villosa Roth.) olmak üzere 3 fiğ türü bitki materyali olarak kullanılmıştır. Organik gübre kaynağı olarak büyükbaş hayvan gübresi, zeolit ve leonardit kullanılmıştır. Araştırmada ekimle birlikte 3 ton $\mathrm{da}^{-1}$ yanmış büyükbaş hayvan gübresi, $100 \mathrm{~kg} \mathrm{da}^{-1}$ zeolit ve $100 \mathrm{~kg} \mathrm{da}^{-1}$ leonardit uygulaması yapılmıştır. Ayrıca hiç gübre uygulaması yapılmayan kontrol parselleri denemeye dahil edilmiştir. Araştırma tesadüf bloklarında bölünmüş parseller deneme desenine göre planlanmış ve üç tekerrürlü olarak yürütülmüştür. Ana parselleri organik gübreler ve kontrol uygulamaları, alt parselleri ise fiğ türleri oluşturmuştur. Denemede ekim 15 
2017 tarihinde $20 \mathrm{~cm}$ aralıklarla açılmış $5 \mathrm{~m}$ uzunluğunda 6 sıradan oluşan parsellere elle yapılmıştır. Bitkiler 15 Nisan 2018 tarihinde tam çiçeklenme zamanında orakla biçilerek hasat edilmiştir.

Deneme yerinin toprağı ve kullanılan hayvan gübresinin fiziksel ve kimyasal içeriği Çizelge 1 'de verilmiştir. Çizelge 1 'de görüldüğü gibi deneme yerinin toprağı killi-tınlı tekstürde ve hafif alkali reaksiyonlu $(\mathrm{pH}=7.60)$, organik madde içeriği \% 2.30'dur. Hayvan gübresi \%60.05 organik madde, \%1.48 azot içeriği ile bu bileşenler açısından deneme alanı topraklarından daha yüksek değere sahipken, fosfor ve potasyum içeriği deneme alanı topraklarından daha düşüktür.

Çizelge 1. Deneme yeri toprağı ve denemede kullanılan yanmış büyükbaş hayvan gübresinin fiziksel ve kimyasal içeriği Table 1. Physical and chemical content of experiment area soil and burnt cattle manure used in the trial

\begin{tabular}{lcc} 
& Toprak & Hayvan Gübresi \\
Tekstür & Killi-tınlı & - \\
Hacim ağılığı $\left(\mathrm{g} \mathrm{cm}^{-3}\right)$ & 1.25 & 0.28 \\
$\mathrm{pH}$ & 7.60 & 7.05 \\
Iletkenlik $\left(\mathrm{dS} \mathrm{m} \mathrm{m}^{-1}\right)$ & 1.15 & 2.85 \\
Tarla kapasitesi $(\%)$ & 27.50 & - \\
Organik madde (\%) & 2.30 -düşük & 60.05 -yüksek \\
Azot (\%) & 0.150 -düşük & 1.48 -yüksek \\
Mineral azot (\%) & 1.35 & - \\
Fosfor $\left(\mathrm{mg} \mathrm{kg}^{-1}\right)$ & 4.80 -yeterli & 1.28 -düšük \\
Potasyum $\left(\mathrm{mg} \mathrm{kg}^{-1}\right)$ & 390 -yüksek & 0.17 -düşük \\
\hline
\end{tabular}

Deneme yerinin ekim sezonuna ve uzun yıllar ortalamasına ait iklim verileri Çizelge 2 'de verilmiştir.

Çizelge 2'de görüldüğü gibi, denemenin yürütüldüğü aylarda sıcaklık ve yağış uzun yıllar ortalamasına göre nispeten daha yüksek seyretmiştir. Fakat bu ayların yağış toplamı uzun yıllar ortalamasından daha düşük olmuştur. Kasım ayında gerçekleşen toplam yağış miktarı uzun yıllar ortalamasına yakın gerçekleşirken, Ocak ve Şubat aylarında uzun yıllar ortalamasından daha yüksek, diğer aylarda ise daha düşük yağış kaydedilmiştir. Denemenin yürütüldüğü aylar içerisinde yağış açısından en yüksek yağış Ocak ayında gerçekleşmiştir. Toplam yağışın neredeyse yarısı Ocak ayında toprağa düşmüştür.

Çizelge 2. Deneme yerinin ekim sezonuna ve uzun yıllar ortalamasına ait iklim verileri

Table 2. Climatic values of growing period and long time averages

\begin{tabular}{lcccccc}
\hline Aylar & \multicolumn{2}{c}{ Nispi Nem (\%) } & \multicolumn{2}{c}{ Sıcaklık $\left({ }^{\circ} \mathrm{C}\right)$} & \multicolumn{2}{c}{ Yağış $(\mathrm{mm})$} \\
\hline Kasım & UYO & $2017-2018$ & UYO & $2017-2018$ & UYO & $2017-2018$ \\
Aralık & 66.5 & 72.1 & 13.6 & 14.6 & 34.6 & 35.0 \\
Ocak & 82.0 & 85.8 & 8.6 & 9.5 & 65.5 & 28.7 \\
Şubat & 84.9 & 86.4 & 7.5 & 9.1 & 95.2 & 120.2 \\
Mart & 76.0 & 83.1 & 9.7 & 11.8 & 58.5 & 75.2 \\
Nisan & 70.4 & 73.7 & 13.2 & 15.8 & 54.6 & 10.2 \\
\hline Toplam & 64.8 & 64.1 & 17.5 & 19.2 & 39.7 & 15.0 \\
\hline Ortalama & - & - & - & - & 348.1 & 284.3 \\
\hline
\end{tabular}

*Hatay Meteoroloji il Müdürlüğü; UYO: Uzun Yıllar Ortalaması

\section{Yöntem}

Bitki boyu (BB) için çiçeklenme döneminde hasat yapılmadan önce parsellerden rastgele seçilen 10 bitkide ölçüm yapılmış, bu değerlerin ortalaması alınmış ve kaydedilmiştir (Yılmaz ve ark., 2018). Parsellerde kenar tesirleri (parsellerin sağından ve solundan bir sıra, biçilen sıraların başından ve sonundan $0.5 \mathrm{~cm}$ ) çıkarıldıktan sonra kalan alandaki bitkiler biçilerek hemen tartılmış ve parsel yaş ağırlığı olarak kaydedilmiştir. Buradan elde edilen yaş ağırlıklar üzerinden parsellerin yeşil ot verimi (YOV) dekara çevrilerek hesaplanmıştır. Parsellerden biçilen yaş ottan $500 \mathrm{~g}$ örnek ayrılmış ve $65^{\circ} \mathrm{C}$ 'de sabit ağırlığa gelinceye kadar kurutulmuş ve kuru ağırlıklar tartılmıştır. Kuru ağırlık ve yaş ağırlık oranından 
yararlanarak bitkilerin kuru ağırlık oranları hesaplanmış ve bu oran üzerindin parsellerin kuru ot verimleri (KOV) dekara çevrilerek hesap edilmiştir. Kurutulmuş bitki örnekleri $1 \mathrm{~mm}$ elek çapından geçirilerek öğütülmüş (Ertekin ve ark., 2019; Ertekin ve Kızılşimşek, 2020) ve kimyasal analizlere hazır hale getirilmiştir. Ögütülen bu örneklerin kuru madde oranları $105^{\circ} \mathrm{C}$ 'de en az 24 saat süre ile etüvde bekletilerek belirlenmiş (Keppler ve ark., 2006) ve tüm kimyasal analiz sonuçları kuru madde tabanında \% (yüzde) olarak ifade edilmiştir. Bitki türlerinin ham kül (HK) içerikleri AOAC (1990)'a göre yapılmış ve organik madde (OM) içeriği bu değerler üzerinden hesaplanmıştır. Örneklerin azot $(N)$ içeriği Kjeldahl metoduna göre belirlenmiş (AOAC, 1990) ve ham protein içeriği $N \times 6.25$ formülü ile hesaplanmıştır. Nötr ortamda çözünmeyen lif (NDF) ve asitli ortamda çözünmeyen lif (ADF) içerikleri Van Soest ve ark. (1991)'na göre ANKOM filtre torbası tekniği kullanılarak ANKOM A220 lif analiz cihazı (ANKOM Teknoloji, Fairport, NY) vasıtasıyla belirlenmiştir. Asitli ortamda çözünmeyen lignin (ADL) içeriği $\% 72$ 'lik $\quad \mathrm{H}_{2} \mathrm{SO}_{4}$ kullanılarak beher tekniği (ANKOM Teknoloji) ile belirlenmiştir. Hayvanın canlı ağırlığı (CA) temelinde kuru madde tüketimi (KMT) NDF içeriğinden, sindirilebilir kuru madde (SKM) ve ADF içeriklerinden yararlanarak aşağıdaki formüllere göre hesaplanmıştır (Van Dyke ve Anderson, 2002). Nispi yem değeri (NYD) Van Dyke ve Anderson (2002)'un bildirdiği yönteme göre \%SKM ve \%KMT değerleri kullanılarak belirlenmiştir.

KMT $(\%$ CA $)=120 /$ NDF $(\%)$

SKM $(\%)=88.9-(0.779 \times A D F(\%))$

NYD $=($ SKM $(\%) \times K M T(\%)) / 1.29$

Bu çalışmadan elde edilen veriler SAS JMP 13.0 istatistik paket programında tesadüf bloklarında bölünmüş parseller deneme desenine göre varyans analizine tabi tutulmuştur. Varyans analizi neticesinde $\mathrm{P}<0.05$ hata sınırında farklı çıkan özelliklerde Tukey çoklu karşılaştırma testi uygulanmıştır. Ortalama verilerle birlikte \pm standart hata değerleri de tablolarda verilmiştir.

\section{BULGULAR ve TARTIŞMA}

Bitki boyu değerlerine uygulanan varyans analiz sonuçları, bitki boyunun fiğ türlerine bağlı olarak önemli derecede değiştiğini, ancak organik gübrelerin ve organik gübrexfiğ türü interaksiyonunun ise bitki boyu üzerindeki etkisinin istatistiksel olarak önemsiz olduğunu göstermiştir (Çizelge 3). Gübre ortalamaları 117.83$120.89 \mathrm{~cm}$ arasında değişmiş, ancak bu değişim istatistiksel olarak önemsiz olmuştur. Uygulanan organik gübrelerin hiç birisi fiğ türlerinin bitki boyunda kontrole göre önemli bir farklılık meydana getirmemiştir. Yolcu (2011) organik gübrelemenin yaygın fiğin bitki boyu üzerine etkisinin yıllara bağlı olarak değiştiğini, ilk yıl bitki boyu üzerine organik gübrelerin etkisinin önemli olduğunu, ancak araştırmanın ikinci yılında gübre uygulamaları ve kontrol arasında önemli bir farklılık olmadığını bildirmiştir. Gül ve ark. (2015) ise leonardit ve zeolit uygulamalarının fiğ bitki boyunu arttırdığını bildirmişlerdir. Fiğ türlerinin ortalama bitki boyları yaygın fiğ, Macar fiği ve tüylü fiğ için sırasıyla 123.40, 86.15 ve $148.73 \mathrm{~cm}$ olarak belirlenmiştir (Çizelge 3). Bu bulgularımıza paralel olarak Zeybek (2010) fiğ türlerinin bitki boyunun uzundan kısaya doğru tüylü fiğ, yaygın fiğ ve Macar fiği şeklinde sıralandığını bildirmiş̧ir. Benzer şekilde Kendir (1999) tüylü fiğin diğer türlerden daha uzun boylu olduğunu ancak bizim bulgularımızın aksine Macar fiği bitki boyunun yaygın fiğden daha uzun olduğunu bildirmişlerdir. Bu durum fiğ türlerinin iklim ve toprak özelliklerine farklı tepki göstermesinden kaynaklanmış olabilir. Organik gübrexfiğ türü interaksiyonu açısından bitki boyu değerleri 82.37$155.17 \mathrm{~cm}$ arasında değişiklik göstermiştir. Interaksiyonun önemsiz çıkması bitki boyu açısından belirleyici faktörün fiğ türü olduğunu göstermektedir. Diğer bir ifade ile, fiğ türleri, uygulanan organik gübre dozlarına benzer tepkiler vermiştir. Farklı ekolojik koşullarda fiğ türleri ile yürütülen araştırmalarda (Tosun ve ark., 1991; Yolcu, 2011; Turna ve Ertuş, 2017) bitki boyunun geniş bir skalada değiştiği görülmüştür. Bu durum fiğ türlerinin bitki boyunun genotip, çevre faktörleri ve uygulanan yetiştirme tekniklerinin etkisi altında olduğunu göstermektedir.

Yeşil ot verimleri farklı gübre uygulamalarına bağlı olarak $1893.56 \mathrm{~kg} \mathrm{da}^{-1}$ ile $2231.56 \mathrm{~kg} \mathrm{da}^{-1}$ arasında değişim göstermiştir, ancak uygulamalar arasındaki bu farklılık istatistiksel olarak önemli bulunmamıştır (Çizelge 4). Kontrol, leonardit ve hayvan gübresi uygulamalarında dekardan 2 ton/da (veya $2000 \mathrm{~kg} / \mathrm{da}$ ) üzerinde yeşil ot verimi elde edilirken, zeolit uygulamasında istatistiksel olarak önemsiz olmakla birlikte daha düşük verimler elde edilmesi dikkat çekicidir. Yolcu (2011) yaygın fiğ verimi üzerine orta düzeyde $\left(2\right.$ ton da $\left.^{-1}\right)$ katı hayvan gübresinin zeolit, leonardit ve sıvı çiftlik gübresine göre daha etkin olduğunu, ancak gübre etkinliğinin yıllara göre değiştiğini bildirmiştir. 
Çizelge 3. Farklı organik gübrelerle yetiştirilen fiğ türlerinin BB $(\mathrm{cm})$ değerleri

Table 3. Plant height $(\mathrm{cm})$ values of vetch species grown with different organic fertilizers

\begin{tabular}{lllll}
\hline & Yaygın Fiğ \pm SE & Macar Fiğ \pm SE & Tüylü Fiğ $\pm S E$ & Gübre Ort. \pm SE \\
\hline Kontrol & $127.40 \pm 18.31$ & $90.67 \pm 21.69$ & $144.60 \pm 10.59$ & $120.89 \pm 11.82$ \\
Zeolit & $119.83 \pm 3.60$ & $85.03 \pm 2.05$ & $151.83 \pm 0.63$ & $118.90 \pm 9.72$ \\
Leonardit & $122.70 \pm 7.91$ & $82.37 \pm 3.01$ & $155.17 \pm 13.55$ & $120.08 \pm 11.49$ \\
Hayvan Gübresi & $123.67 \pm 5.41$ & $86.53 \pm 12.03$ & $143.30 \pm 4.48$ & $117.83 \pm 9.24$ \\
\hline Tür Ort. $\pm S E$ & $123.40 \pm 4.55^{\mathrm{B}}$ & $86.15 \pm 5.42^{\mathrm{C}}$ & $148.73 \pm 4.07^{\mathrm{A}}$ & \\
\hline
\end{tabular}

SE: Standart hata; Ort.: Ortalama

Aynı satırda farklı harflerle gösterilen değerler birbirinden farklıdır $(P<0.05)$.

Nitekim, araştırıcı araştırmanın ikinci yılında en yüksek verimin kontrol uygulamasında elde edildiğine dikkat çekmiştir. Bununla birlikte Gül ve ark. (2015) organik gübre kaynaklarının ayrı ayrı kullanılmasından ziyade karıştıılarak kullanılmasının fiğ yaş ve kuru ot verimini arttırdığını, özellikle bu noktada ahır gübresi+leonardit karışımının iyi sonuç verdiğini bildirmiştir. Yeşil ot verimi açısından fiğ türleri arasındaki farklııı istatistiksel olarak önemli bulunmuştur. Tüylü fiğ $2374.00 \mathrm{~kg} \mathrm{da}^{-1}$ ile en yüksek yeşil ot verimine sahip fiğ türü olurken, 1900.33 $\mathrm{kg} \mathrm{da}^{-1}$ yeşil ot verim ile yaygın fiğ en düşük verime sahip fiğ türü olmuştur. Macar fiğinde belirlenen yeşil ot verimi değeri ise diğer iki tür ile istatistiksel olarak benzer olmuştur (Çizelge 4). Tüylü fiğin ot veriminin diğer türlere göre yüksek olduğu diğer araştırıcılar tarafından da belirlenmiştir (Güzeloğulları ve Albayrak, 2016; Turna ve Ertuş, 2017; Erol ve Anlarsal, 2019). Organik gübrex fiğ türü interaksiyonları değerlendirildiğinde yeşil ot verimleri $1661.33-2809.33 \mathrm{~kg} \mathrm{da}^{-1}$ arasında değişmiş ancak bu değişim istatistiksel olarak önemsiz bulunmuştur (Çizelge 4). İstatistiksel olarak önemli olmamakla birlikte, hayvan gübresi uygulanan tüylü fiğde belirlenen $2809.00 \mathrm{~kg} \mathrm{da}^{-1}$ yeşil ot verimi dikkat çekicidir. Bununla birlikte, tüylü fiğin gübre uygulanmadan yetiştirildiği kontrol uygulamasında ikinci yüksek verimin elde edilmesi, iki uygulamanın ekonomik açıdan değerlendirilmesi gerektiğini göstermektedir.

Çizelge 4. Farklı organik gübrelerle yetiştirilen fiğ türlerinin yeşil ot verimi değerleri $\left(\mathrm{kg} \mathrm{da}^{-1}\right)$

Table 4. Fresh forage yield $\left(\mathrm{kg} \mathrm{da}^{-1}\right)$ values of vetch species grown with different organic fertilizers

\begin{tabular}{lllll}
\hline & Yaygın Fiğ \pm SE & Macar Fiği \pm SE & Tüylü Fiğ \pm SE & Gübre Ort. \pm SE \\
\hline Kontrol & $1948.00 \pm 221.50$ & $2001.33 \pm 343.66$ & $2416.00 \pm 581.00$ & $2121.78 \pm 218.01$ \\
Zeolit & $1864.00 \pm 218.88$ & $2155.33 \pm 236.70$ & $1661.33 \pm 221.91$ & $1893.56 \pm 133.80$ \\
Leonardit & $2072.00 \pm 172.62$ & $1858.67 \pm 248.82$ & $2069.33 \pm 542.44$ & $2180.00 \pm 211.26$ \\
Hayvan Gübresi & $1717.33 \pm 309.89$ & $2168.00 \pm 305.16$ & $2809.33 \pm 417.03$ & $2231.56 \pm 235.27$ \\
\hline Tür Ort. $\pm S E$ & $1900.33 \pm 107.89^{\mathrm{B}}$ & $2045.83 \pm 128.12^{\mathrm{AB}}$ & $2374.00 \pm 236.67^{\mathrm{A}}$ & \\
\hline
\end{tabular}

SE: Standart hata; Ort.: Ortalama

Aynı satırda farklı harflerle gösterilen değerler birbirinden farklıdır( $P<0.05)$.

Kuru ot verimi değerlerine ait ortalamalar Çizelge $5^{\prime}$ de verilmiştir. Çizelge $5^{\prime}$ den de görüldüğü gibi deneme faktörlerinin hiç birisi kuru ot verimleri arasında istatistiki anlamda bir fark oluşturmamıştır. Kuru ot verimi değerleri organik gübre kaynaklarına bağıı olarak önemsiz olmakla birlikte, hayvan gübresi ve leonardit uygulamalarının kuru ot verimi üzerinde olumlu etkisinin olduğu söylenebilir. Gül ve ark. (2015) yaygın fiğde leonardit ve zeolit uygulamalarının verimi çiftlik gübresine göre daha fazla arttırdığını, bununla birlikte gübre kaynaklarının birlikte kombine edilmesinin daha etkili olduğunu bildirmişlerdir. Yolcu (2010) yaygın fiğ yaş ve kuru ot verimi üzerine en iyi organik gübre uygulamasının 2 ton da $^{-1}$ katı sığır gübresi uygulaması olduğunu, zeolitin düşük $\left(25 \mathrm{~kg} \mathrm{da}^{-1}\right)$ ve leonarditin orta
(50 kg da ${ }^{-1}$ ) düzey uygulamalarında verimin arttığııı, ancak daha yüksek dozların kontrolden farksız olduğunu belirlemiştir. Bu durum çalıştığımız ekolojik koşullar için uygun doz belirleme çalışmalarının faydalı olabileceğini göstermektedir. Kuru ot verimleri fiğ türleri arasında istatistiksel olarak önemli bir farklılık göstermemiş, ortalama kuru ot verimleri yaygın fiğ, Macar fiği ve tüylü fiğ için sırasıyla 324.90, 333.75 ve $381.29 \mathrm{~kg} \mathrm{da}^{-1}$ olarak belirlenmiştir. İstatistiksel olarak önemli olmamakla birlikte araştırmaya konu olan fiğ türleri içerisinde tüylü fiğin daha iyi performans gösterdiği söylenebilir. Bulgularımıza uygun olarak, Güzeloğulları ve Albayrak (2016) aynı fiğ türleri ile yürüttükleri çalışmada tüylü fiğin daha yüksek verim verdiğini, bunu Macar fiği ve yaygın fiğin takip ettiğini bildirmişlerdir. Ülkemizde fiğ 
türleri ile yapılan araştırmalarda kuru ot verimlerinin büyük bir varyasyon gösterdiği görülmektedir (Açıkgöz ve Çelik, 1986; Şılbır ve ark., 1991; Tosun ve ark., 1991; Yılmaz ve ark., 1996; Sevimay ve Kendir,1996; Kokten ve ark., 2009; Atis ve ark., 2012). Bu durum hem ekolojik koşulların hem de yetiştirme tekniklerinin fiğ türlerinin kuru ot verimini önemli derecede etkilediğini göstermektedir.
Kuru ot verimleri organik gübrexfiğ türü interaksiyonu açısından değerlendirildiğinde interaksiyonun önemsiz olduğu, ancak tüm uygulamalar içerisinde hayvan gübresi uygulanan tüylü fiğin en başarılı uygulama olduğu, bunu leonardit uygulanan tüylü fiğin takip ettiği söylenebilir. Diğer iki fiğ türünden ise yaygın fiğin leonardit, Macar fiğinin ise zeolit uygulamasına daha iyi tepki gösterdiği söylenebilir.

Çizelge 5. Farklı organik gübrelerle yetiştirilen fiğ türlerinin KOV $\left(\mathrm{kg} \mathrm{da}^{-1}\right)$ değerleri

Table 5. Dry forage yield $\left(\mathrm{kg} \mathrm{da}^{-1}\right)$ values of vetch species grown with different organic fertilizers

\begin{tabular}{lllll}
\hline & Yaygın Fiğ \pm SE & Macar Fiğ \pm SE & Tüylü Fiğ $\pm S E$ & Gübre Ort. \pm SE \\
\hline Kontrol & $307.92 \pm 25.43$ & $297.00 \pm 58.52$ & $344.82 \pm 118.56$ & $316.58 \pm 39.57$ \\
Zeolit & $319.91 \pm 37.29$ & $369.75 \pm 54.30$ & $237.59 \pm 40.84$ & $309.08 \pm 29.53$ \\
Leonardit & $370.84 \pm 47.89$ & $319.22 \pm 56.50$ & $403.97 \pm 114.83$ & $364.68 \pm 41.33$ \\
Hayvan Gübresi & $300.92 \pm 46.49$ & $349.05 \pm 35.98$ & $538.78 \pm 117.64$ & $396.25 \pm 52.53$ \\
\hline Tür Ort. \pm SE & $324.90 \pm 19.06$ & $333.75 \pm 23.78$ & $381.29 \pm 54.94$ & \\
\hline
\end{tabular}

SE: Standart hata; Ort.: Ortalama

Deneme faktörlerinin ve interaksiyonların ham kül değerlerine etkisi istatistiki anlamda önemli bulunmamıştır. Gübre ortalamaları açısından ham kül değerleri \%10.10-11.24 arasında değişirken, fiğ türü ortalamaları açısından bu değerler \%10.59-11.18 arasında değişmiştir. İnteraksiyonlara bağlı olarak ham kül değerleri \%10.06-11.75 arasında değişmiştir. Çaçan ve ark. (2018) yaygın fiğ hat ve çeşitlerinde ham kül değerlerini \%10.3-13.9 arasında tespit etmişlerdir. Buna ek olarak, Özyiğit ve Bilgen (2006) üç farklı hasat zamanında (çiçeklenme başlangıcı, \% 50 çiçeklenme ve tam çiçeklenme) ham kül oranını tüylü fiğde erken hasattan geç hasada doğru sırasıyla \% 11.22, 10.08 ve 8.60 ve yaygın fiğde ise yine aynı hasat zamanlarında $\% 10.75,9.90$ ve 7.76 olarak rapor etmişlerdir. Yücel ve ark. (2014) iki lokasyonda farklı yaygın fiğ genotiplerinin ham kül oranı için \% 9.50-10.95 arasında değerler ile bildirmişlerdir. Bu çalışmadan elde edilen ham kül değerleri yukarıda bildirilen fiğ türlerindeki ham kül değerleri ile uyumludur.

Çizelge 6. Farklı organik gübrelerle yetiştirilen fiğ türlerinin ham kül $\left(\% \mathrm{KM}^{-1}\right)$ değerleri

Table 6. Crude ash $\left(\% \mathrm{DM}^{-1}\right)$ values of vetch species grown with different organic fertilizers

\begin{tabular}{lllll}
\hline & Yaygın Fiğ \pm SE & Macar Fiğ \pm SE & Tüylü Fiğ $\pm S E$ & Gübre Ort. \pm SE \\
\hline Kontrol & $10.68 \pm 0.41$ & $11.58 \pm 0.28$ & $11.46 \pm 0.45$ & $11.24 \pm 0.24$ \\
Zeolit & $10.80 \pm 0.16$ & $10.75 \pm 0.29$ & $11.75 \pm 0.72$ & $10.10 \pm 0.28$ \\
Leonardit & $10.13 \pm 0.76$ & $11.62 \pm 0.40$ & $11.03 \pm 0.22$ & $10.93 \pm 0.34$ \\
Hayvan Gübresi & $10.77 \pm 0.42$ & $10.78 \pm 0.68$ & $10.06 \pm 0.50$ & $10.54 \pm 0.30$ \\
\hline Tür Ort. $\pm S E$ & $10.59 \pm 0.22$ & $11.18 \pm 0.23$ & $11.07 \pm 0.29$ &
\end{tabular}

SE: Standart hata; Ort.: Ortalama

Organik madde değerlerine ait ortamalar Çizelge 7'de verilmiştir. Çizelgede de görüldüğü üzere tüm uygulamalar ve interaksiyonlar arasında istatistiki anlamda bir fark ortaya çıkmamıştır. Organik gübre kaynaklarına bağlı olarak organik madde değerleri \% 88.76-89.46 arasında bulunurken, fiğ türlerine bağlı olarak organik madde içerikleri \%88.82-89.41 arasında bulunmuştur. Interaksiyonlar arasında ise organik madde değerleri \%88.25-89.94 arasında değişiklik göstermiştir. Canbolat ve Karaman (2009) tüylü fiğde organik maddeyi \%93.81 olarak bulduğunu bildirmiştir. Aksoy ve Nursoy (2010) 7 farklı biçim zamanında Macar fiğinde organik maddeyi havada kuru içeriğinde \% 83.8484.96 arasında değişen farklı değerlerde tespit etmişlerdir. Bu çalışmadan elde edilen organik madde değerleri Aksoy ve Nursoy (2010)'un sonuçlarından yüksek Canbolat ve Karaman (2009)'ın sonuçlarından düşük bulunmuştur. Aksoy ve Nursoy (2010) yaptıkları çalışmada organik madde değerlerini havada kuru olarak belirtmişlerdir. Ayrıca yapılan çalışmalar kapsamında her bitki türü bölge ekolojisine farklı tepkilerde bulunduğundan besinsel içerikleri değişiklik gösterebilmektedir. 
Verilere uygulanan istatistiksel analiz sonuçları ham protein oranlarının fiğ türleri ve organik gübrexfiğ türü interaksiyonundan önemli derecede etkilendiğini, ancak organik gübre kaynaklarının ham protein içeriği üzerine etkisinin önemli olmadığını göstermiştir (Çizelge 8). Organik gübre kaynaklarına bağlı olarak ham protein oranları \%20.17-21.19 arasında bulunmuştur(Çizelge 8). Gül ve ark. (2015) farklı organik gübre kaynakları ve kimyasal gübre uyguladıkları yaygın fiğde ham protein oranlarının \%17.3 ile \%19.5 arasında değiştiğini ve leonardit ve zeolit uygulamalarının ham protein içeriğini azalttığını belirlemişlerdir. Araştırıcılar ayrıca ahır gübresinin leonardit ve zeolit ile ikili karışımlar halinde uygulanmasının ham protein içeriğini olumlu etkilediğini belirlemişlerdir.

Çizelge 7. Farklı organik gübrelerle yetiştirilen fiğ türlerinin organik madde $\left(\% \mathrm{KM}^{-1}\right)$ içerikleri

Table 7. Organic matter $\left(\% D M^{-1}\right)$ contents of vetch species grown with different organic fertilizers

\begin{tabular}{lllll}
\hline & Yaygın Fiğ $\pm S E$ & Macar Fiğ $\pm S E$ & Tüylü Fiğ $\pm S E$ & Gübre Ort. $\pm S E$ \\
\hline Kontrol & $89.32 \pm 0.41$ & $88.42 \pm 0.28$ & $88.54 \pm 0.45$ & $88.76 \pm 0.24$ \\
Zeolit & $89.20 \pm 0.16$ & $89.25 \pm 0.29$ & $88.25 \pm 0.72$ & $88.90 \pm 0.28$ \\
Leonardit & $89.87 \pm 0.76$ & $88.38 \pm 0.40$ & $88.97 \pm 0.22$ & $89.07 \pm 0.34$ \\
Hayvan Gübresi & $89.23 \pm 0.42$ & $89.22 \pm 0.68$ & $89.94 \pm 0.50$ & $89.46 \pm 0.30$ \\
\hline Tür Ort. $\pm S E$ & $89.41 \pm 0.22$ & $88.82 \pm 0.23$ & $88.93 \pm 0.29$ & \\
\hline
\end{tabular}

SE: Standart hata; Ort.: Ortalama

Yolcu (2011) fiğde leonardit, zeolit ve ahır gübresi kullandığı çalışmada tüm gübre uygulamalarının ham protein içeriğini kontrole göre arttırdığını bildirmiştir. Çalışmamızdan elde ettiğimiz bir başka sonuca göre fiğ türlerine bağlı olarak ham protein oranları \%19.99-21.82 arasında değişim göstermiştir. İncelenen fiğ türlerinden yaygın fiğin ham protein içeriği diğer iki türden istatistiksel olarak daha yüksek olmuştur. Güzeloğulları ve Albayrak (2016) yaygın fiğ, Macar fiği ve tüylü fiğde üç farklı hasat zamanında ham protein oranlarını değerlendirmişler ve yaygın fiğde \% 18.73-24.18, Macar fiğinde \% 17.66-24.89 ve tüylü fiğde \% 16.74-27.71 arasında bulmuşlardır. Çaçan ve ark. (2018) bazı yaygın fiğ hat ve çeşitlerinde ham protein oranlarını \% 14.2-20.0 arasında rapor etmişlerdir. Erol ve ark. (2009) yaygın fiğde ham protein oranını \% $22.29 \mathrm{KM}^{-1}$ olarak bildirmişlerdir. Yücel ve ark. (2014) ümitvar bazı yaygın fiğ genotiplerinde ham protein oranını \% 15.9-19.6 arasında rapor etmişlerdir. Bu çalışmadan elde edilen ham protein oranları yukarıda belirtilen çalışmalarda belirlenen değerler arasındadır. İnteraksiyon incelendiği zaman, ham protein oranlarının \% 18.89-22.54 arasında değiştiği görülmektedir. En yüksek ham protein hayvan gübresi uygulaması ile yaygın fiğ türünden elde edilirken en düşük ise kontrolde tüylü fiğ türünde tespit edilmiştir.

Çizelge 8. Farklı organik gübrelerle yetiştirilen fiğ türlerinin ham protein oranları $\left(\% \mathrm{KM}^{-1}\right)$

Table 8. Crude protein ratios $\left(\% D^{-1}\right)$ of vetch species grown with different organic fertilizers

\begin{tabular}{lllll}
\hline & Yaygın Fiğ \pm SE & Macar Fiğ \pm SE & Tüylü Fiğ $\pm S E$ & Gübre Ort. \pm SE \\
\hline Kontrol & $21.64 \pm 0.50^{\mathrm{ab}}$ & $19.99 \pm 0.20^{\mathrm{ab}}$ & $18.89 \pm 1.43^{\mathrm{b}}$ & $20.17 \pm 0.59$ \\
Zeolit & $22.27 \pm 0.89^{\mathrm{ab}}$ & $21.82 \pm 0.65^{\mathrm{ab}}$ & $19.48 \pm 0.76^{\mathrm{ab}}$ & $21.19 \pm 0.58$ \\
Leonardit & $20.85 \pm 1.08^{\mathrm{ab}}$ & $19.42 \pm 0.39^{\mathrm{ab}}$ & $22.13 \pm 0.86^{\mathrm{ab}}$ & $20.80 \pm 0.57$ \\
Hayvan Gübresi & $22.54 \pm 0.91^{\mathrm{a}}$ & $20.22 \pm 0.58^{\mathrm{ab}}$ & $19.46 \pm 0.25^{\mathrm{ab}}$ & $20.74 \pm 0.56$ \\
\hline Tür Ort. $\pm S E$ & $21.82 \pm 0.42^{\mathrm{A}}$ & $20.36 \pm 0.34^{\mathrm{B}}$ & $19.99 \pm 0.55^{\mathrm{B}}$ &
\end{tabular}

SE: Standart hata; Ort.: Ortalama

Aynı satır ve/veya sütunda farklı harflerle gösterilen değerler birbirinden farklıdır $(P<0.05)$.

NDF değerlerine ait ortamalar Çizelge $9^{\prime}$ da verilmiştir. Verilere uygulanan varyans analiz sonuçları deneme faktörlerinin NDF değerleri üzerine etkisinin önemli olmadığını göstermiştir. Organik gübre kaynaklarına bağlı olarak NDF değerleri \%48.48-50.99 arasında değişirken, fiğ türlerine bağlı olarak \%49.02 ve 50.45 arasında değişmiştir. İnteraksiyonlar için NDF değerleri \%46.81-51.79 arasında değişiklik göstermiştir. Tüm deneme konuları içerisinde leonardit uygulanan yaygın fiğ \%46.81 NDF oranıyla ile en düşük değerin kaydedildiği uygulama olurken, bunu \%47.11 ile zeolit uygulanan Macar fiği takip etmiştir. Bulgularımıza paralel olarak Yolcu (2011) ve Gül ve ark. (2015) farklı organik gübre kaynaklarının fiğin NDF oranı üzerine etkisinin önemsiz olduğunu bildirmişlerdir. Yemlerdeki NDF içeriğinin miktarı ruminantlar tarafından yem alımını ve sindirimini 
etkileyen en önemli parametrelerden biridir (Yavuz, 2005; Canbolat ve Karaman, 2009). Güzeloğulları ve Albayrak (2016) yaygın fiğ, Macar fiği ve tüylü fiğde üç farklı hasat zamanında NDF oranlarını değerlendirmişler ve yaygın fiğde \%30.37-36.86, Macar fiğde \%33.21-38.68 ve tüylü fiğde \%34.92-42.26 arasında bulmuşlardır. Çaçan ve ark. (2018) bazı yaygın fiğ hat ve çeşitlerinde NDF oranlarını \% 34.8-45.0 arasında rapor etmişlerdir. Erol ve ark. (2009) yaygın fiğde NDF oranını \%40.60 olarak bildirmişlerdir. Yücel ve ark. (2014) ümitvar bazı yaygın fiğ genotiplerinde NDF oranını \%35.3-44.4 arasında rapor etmişlerdir. Bu çalışmadan elde edilen NDF değerleri literatürlerde bildirilen değerlerden bir miktar yüksek bulunmuştur. Bu durum kullanılan genotiplerin, amenajman tekniklerinin ve ekolojilerin farklı olmasının neden olduğu düşünülmektedir. Ayrıca hasat zamanı NDF içeriğinin değişiminde önemli bir rol oynamaktadır.

Çizelge 9. Farklı organik gübrelerle yetiştirilen fiğ türlerinin NDF $\left(\% \mathrm{KM}^{-1}\right)$ değerleri

Table 9. NDF $\left(\% D M^{-1}\right)$ values of vetch species grown with different organic fertilizers

\begin{tabular}{lllll}
\hline & Yaygın Fiğ \pm SE & Macar Fiğ $\pm S E$ & Tüylü Fiğ $\pm S E$ & Gübre Ort. \pm SE \\
\hline Kontrol & $49.63 \pm 1.69$ & $51.79 \pm 0.30$ & $51.56 \pm 2.80$ & $50.99 \pm 1.01$ \\
Zeolit & $49.99 \pm 0.74$ & $47.58 \pm 1.49$ & $51.63 \pm 1.06$ & $49.73 \pm 0.82$ \\
Leonardit & $46.81 \pm 1.33$ & $50.83 \pm 1.01$ & $48.11 \pm 1.24$ & $48.48 \pm 0.84$ \\
Hayvan Gübresi & $49.65 \pm 0.49$ & $51.60 \pm 1.17$ & $49.66 \pm 2.82$ & $50.31 \pm 0.95$ \\
\hline Tür Ort. $\pm S E$ & $49.02 \pm 0.63$ & $50.45 \pm 0.69$ & $49.02 \pm 1.02$ &
\end{tabular}

SE: Standart hata; Ort.: Ortalama

ADF oranları bakımından gübre uygulamaları ve interaksiyonlar arasında istatistiki bir farklılık oluşmazken fiğ türleri arasındaki farklıık istatistiki olarak önemli bulunmuştur. Gübre uygulamaları açısından ADF içerikleri \%31.52-34.34 arasında değişmiş, zeolit ve leonardit uygulamalarında rakamsal olarak daha düşük değerler kaydedilmekle birlikte bu farklılık istatistiksel olarak önemli olmamıştır (Çizelge 10). Bulgularımızla uyumlu olarak Yolcu (2011) ve Gül ve ark. (2015) yaygın fiğin ADF oranı üzerine zeolit, leonardit ve hayvan gübresi uygulamalarının önemli bir etkisi olmadığını bildirmişlerdir. Farklı organik gübre kaynakları uygulanan fiğde Gül ve ark. (2015)'in belirlediği değerler (\%32.5834.98) belirlediğimiz değerlere oldukça yakın olurken, Yolcu (2011) biraz daha düşük değerler bildirmiştir. Fiğ türleri açısından ADF oranları arasındaki farklıık istatistiksel olarak önemli bulunmuştur. Yaygın fiğ \%30.58 ile en düşük ADF oranına sahip tür olurken, tüylü fiğ en yüksek ADF oranına (\%35.05) sahip tür olmuştur.
Macar fiğinin ADF oranı (\%32.78) ise diğer iki türün ara grubunda yer almıştır. Sonuçlar, fiğ türlerinin ADF oranlarının düşükten yükseğe doğru yaygın fiğ, Macar fiği ve tüylü fiğ şeklinde sıralandığını bildiren Güzeloğulları ve Albayrak (2016)'ın bulgularını destekler niteliktedir. İnteraksiyonları incelendiğinde ADF oranlarının \%28.4736.77 arsında değiştiği görülmektedir. Tüm gübre uygulamaları için en düşük ADF oranları yaygın fiğde belirlenmiş, bunu sırasıyla Macar fiği ve tüylü fiğ takip etmiştir. Yemlerdeki ADF içeriğinin miktarı ruminantlar tarafından yem alımını ve sindirimini etkileyen en önemli parametrelerden biridir (Yavuz, 2005; Canbolat ve Karaman, 2009). Bu nedenle düşük ADF oranı yem bitkilerinde istenen bir durumdur. Değişik araştırmalarda fiğ türlerinin ADF oranlarının \%25.43 ile 35.80 arasında değiştiği bildirilmiştir (Erol ve ark., 2009; Yücel ve ark., 2014; Çaçan ve ark., 2018). Elde ettiğimiz değerler bu literatür bildirişleriyle uyumludur.

Çizelge 10. Farklı organik gübrelerle yetiştirilen fiğ türlerinin ADF $\left(\% \mathrm{KM}^{-1}\right)$ değerleri Table 10. ADF $\left(\% D M^{-1}\right)$ values of vetch species grown with different organic fertilizers

\begin{tabular}{lllll}
\hline & Yaygın Fiğ \pm SE & Macar Fiğ $\pm S E$ & Tüylü Fiğ $\pm S E$ & Gübre Ort. $\pm S E$ \\
\hline Kontrol & $32.40 \pm 2.56$ & $33.85 \pm 1.18$ & $36.77 \pm 3.10$ & $34.34 \pm 1.37$ \\
Zeolit & $30.77 \pm 0.27$ & $31.90 \pm 2.66$ & $32.74 \pm 0.99$ & $31.80 \pm 0.87$ \\
Leonardit & $28.47 \pm 0.99$ & $31.65 \pm 2.90$ & $34.44 \pm 1.57$ & $31.52 \pm 1.32$ \\
Hayvan Gübresi & $30.67 \pm 1.22$ & $33.71 \pm 1.12$ & $36.26 \pm 2.23$ & $33.55 \pm 1.14$ \\
\hline Tür Ort. $\pm S E$ & $30.58 \pm 0.77^{\mathrm{B}}$ & $32.78 \pm 0.96^{\mathrm{AB}}$ & $35.05 \pm 1.02^{\mathrm{A}}$ &
\end{tabular}

SE: Standart hata; Ort.: Ortalama

Aynı satırda farklı harflerle gösterilen değerler birbirinden farklıdır $(P<0.05)$. 
ADL değerlerine ait ortalamalar Çizelge 11 'de verilmiştir. Çizelgeden de izlendiği gibi ADL içeriği bakımından uygulamalar ve interaksiyonlar arasında istatistiki bir fark ortaya çıkmamıştır. Gübre ortalamaları ADL değerleri \%5.68-6.49 arasında, fiğ türü ortalamaları ise \%5.86-6.59 arasında değişmiştir. İnteraksiyonların ADL içerikleri ise \%5.30-7.29 arasında tespit edilmiştir. ADL yemdeki ligninin ifadesi olup, yemlerdeki lignin içeriği ruminantlar tarafından ne mikrobiyal enzimler ne de sindirim enzimleri ile sindirilemediği için yemden yararlanmayı olumsuz etkilemektedir (Naser ve ark., 2011). Ek olarak, lignin yemlerde bulunan ve hayvanlar tarafından sindirilerek enerjiye çevrilebilen selüloz ve hemiselülozun sindirimini negatif yönde etkilemektedir
(Sridhar ve Senani, 2011). Akdeniz ve ark. (2018) dört farklı tüylü fiğ çeşidinde ADL içeriklerini \%2.81-3.65 arasında bildirmişlerdir. Macar fiğinde ADL içeriğinin \%6.42 ve 6.55 olduğu tespit edilmiştir (Yolcu ve ark., 2009). Haj Ayed ve ark. (2001) tüy fiğ ve yaygın fiğde üç farklı hasat zamanında ADL içeriklerini sırasıyla \% 8.710.1 ve \% 9.3-9.9 arasında bulmuşlardır. Bu araştırmalarda belirlenen fiğ türlerinin ADL içerikleri değişkenlik göstermekle birlikte, bizim belirlediğimiz ADL oranları literatürlerde belirtilen sınırlar içerisindedir. ADL oranları arasındaki bu farklılıkların kullanılan genotiplerin, yetiştirme tekniklerinin ve ekolojilerin farklı olması yanında hasat zamanındaki farklılıklardan kaynaklandığı düşünülmektedir.

Çizelge 11. Farklı organik gübrelerle yetiştirilen fiğ türlerinin ADL $\left(\% \mathrm{KM}^{-1}\right)$ değerleri

Table 11. ADL $\left(\% D M^{-1}\right)$ values of vetch species grown with different organic fertilizers

\begin{tabular}{lllll}
\hline & Yaygın Fiğ $\pm S E$ & Macar Fiğ $\pm S E$ & Tüylü Fiğ $\pm S E$ & Gübre Ort. $\pm S E$ \\
\hline Kontrol & $6.08 \pm 0.51$ & $6.00 \pm 0.34$ & $7.24 \pm 0.60$ & $6.44 \pm 0.32$ \\
Zeolit & $5.63 \pm 0.45$ & $6.13 \pm 0.44$ & $5.30 \pm 0.18$ & $5.68 \pm 0.22$ \\
Leonardit & $6.17 \pm 0.59$ & $5.68 \pm 0.76$ & $6.54 \pm 0.38$ & $6.13 \pm 0.32$ \\
Hayvan Gübresi & $5.57 \pm 0.23$ & $6.62 \pm 0.26$ & $7.29 \pm 0.61$ & $6.49 \pm 0.32$ \\
\hline Tür Ort. $\pm S E$ & $5.86 \pm 0.21$ & $6.11 \pm 0.23$ & $6.59 \pm 0.32$ & \\
\hline
\end{tabular}

SE: Standart hata; Ort.: Ortalama

NYD, NDF ve ADF değerleri kullanılarak hesaplanan bir yem kalite indeksidir ve yem kalitesinin değerlendirilmesinde sıklıkla kullanılır (Rohweder ve ark., 1978; Atis ve ark., 2019). NYD değerlerine ait ortamalar Çizelge 12 'de verilmiştir. NYD açısından organik gübre kaynaklarının, fiğ türlerinin ve ikili interaksiyonun etkisi istatistiki anlamda önemsiz bulunmuştur. NYD organik gübre uygulamalarına bağlı olarak 114.00-123.67 arasında bulunurken, fiğ türlerine bağı olarak 114.81-123.86 arasında değişmiştir. Interaksiyona bağlı olarak ise NYD değerleri 112.33132.89 arasında değişiklik göstermiştir. Marten ve ark. (1988)'na göre yemlerin NYD 140'dan yüksek ise çok iyi,
110-139 arası ise iyi, 90-109 arası ise orta ve $75^{\prime}$ den düşük ise kötü olarak nitelendirilmiştir. Buna göre çalışmadan elde edilen NYD sonuçları, tüm uygulamalar için elde edilen yemlerin "iyi" sınıfta yer aldığını göstermektedir. Çaçan ve ark. (2018) bazı yaygın fiğ hat ve çeşitlerinde NYD'ni 129.6-184.0 arasında rapor etmişlerdir. Lithourgidis ve ark. (2006) yaygın fiğde NYD'ni 126.85 olarak tespit etmiştir. Canbolat ve Karaman (2009) tüylü fiğde NYD'ni 157.7 olarak bildirmiştir. Kaplan ve ark. (2019) bazı Macar fiğ genotiplerinde NYD'ni 106.73-124.65 arasında bulmuşlardır. Elde edilen değerler önceki araştırmalarda bildirilen sınırlar içerisinde yer almıştır.

Çizelge 12. Farklı organik gübrelerle yetiştirilen fiğ türlerinin NYD değerleri

Table 12. Relative feed values of vetch species grown with different organic fertilizers

\begin{tabular}{lllll}
\hline & Yaygın Fiğ \pm SE & Macar Fiğ \pm SE & Tüylü Fiğ \pm SE & Gübre Ort. \pm SE \\
\hline Kontrol & $119.81 \pm 7.58$ & $112.33 \pm 2.26$ & $109.85 \pm 10.64$ & $114.00 \pm 4.11$ \\
Zeolit & $120.87 \pm 1.47$ & $125.65 \pm 7.62$ & $114.33 \pm 2.76$ & $120.28 \pm 2.89$ \\
Leonardit & $132.89 \pm 5.19$ & $117.83 \pm 6.46$ & $120.30 \pm 5.32$ & $123.67 \pm 3.68$ \\
Hayvan Gübresi & $121.86 \pm 2.99$ & $113.10 \pm 4.11$ & $114.74 \pm 9.93$ & $116.57 \pm 3.49$ \\
\hline Tür Ort. $\pm S E$ & $123.86 \pm 2.62$ & $117.23 \pm 2.84$ & $114.81 \pm 3.54$ &
\end{tabular}

Araştırma sonuçları organik hayvancılığın gereksinim duyduğu kaba yemin karşılanması amacıyla yetiştirilen fiğ türlerinin verim ve kalite parametreleri üzerine farklı organik gübrelerin (hayvan gübresi, zeolit ve leonardit) kontrole göre önemli bir farklılık oluşturmadığını göstermiştir. Bu nedenle, benzer ekolojik koşullarda 
organik fiğ yetiştiriciliğinde herhangi bir gübre kullanılmadan fiğ türlerinin ekonomik olarak yetiştirilebileceği sonucuna varılmıştır. Ancak, önceki çalışmaların da ışığı altında özellikle leonardit ve zeolit için farklı uygulama dozlarının kullanıldığı doz belirleme çalışmalarının yapılmasının faydalı olacağı söylenebilir. Bununla birlikte, organik tarımda toprak organik maddesinin arttırılması ve yapısının düzeltilmesi temel hedefi ve özellikle tüylü fiğde sağladığı verim artışı nedeniyle hayvan gübresi uygulanması tavsiye edilebilir. Fiğ türleri arasında tüylü fiğ daha yüksek verim değerlerine sahip tür olurken, yaygın fiğin kalite değerlerinin diğer türlerden daha yüksek olduğu belirlenmiştir. Yüksek verim açısından tüylü fiğin tercih edilmesi gerektiği sonucuna varılmıştır.

\section{ÖZET}

Amaç: Ülkemizde organik gıda talebi son yıllarda giderek artmaktadır. Fakat organik tarım kapsamında hayvansal üretim besleme güçlüklerinden dolayı oldukça zordur. Bu çalışma organik kaba yem üretimi amacıyla yetiştirilen bazı fiğ türlerinin yem verimi ve kalitesi üzerine farklı organik gübre kaynaklarının etkisini belirlemek amacıyla yürütülmüştür.

Yöntem ve Bulgular: Denemede, yaygın fiğ (Vicia sativa L.), macar fiği (Vicia pannonica Crantz) ve tüylü fiğ (Vicia villosa Roth) olmak üzere 3 farklı fiğ türü ve zeolit, leonardit, büyükbaş hayvan gübresi olmak üzere üç farklı organik gübre çalışmanın faktörlerini oluşturmuştur. Ayrıca organik gübre uygulamalarının etkilerini kıyaslayabilmek için gübrelemenin yapılmadığı kontrol muamelesi de kullanılmıştır. Araştırma tesadüf bloklarında bölünmüş parseller deneme desenine göre planlanmış ve üç tekerrürlü olarak yürütülmüştür. Organik gübre uygulamaları altında fiğ türlerinin ot verimi ve kalitesini belirlemek için bitki boyu (BB), yaş ot verimi (YOV), kuru ot verimi (KOV), ham kül (HK), organik madde (OM), ham protein (HP), nötr ortamda çözünmeyen lif (NDF), asitli ortamda çözünmeyen lif (ADF), asitli ortamda çözünmeyen lignin (ADL), ve nispi yem değeri (NYD) özellikleri incelenmiştir. Çalışmanın sonuçlarına göre, fiğ türleri arasında $B B, Y O V, H P$ ve $A D F$, açısından istatistiki anlamda bir fark bulunurken, sadece HP bakımından faktörler arasında önemli bir interaksiyon oluşmuştur. Fiğ türlerinin $\mathrm{BB}, \mathrm{YOV}, \mathrm{HP}$ ve ADF değerleri sırasıyla 86.15-148.73 cm, 1900.33$2045.83 \mathrm{~kg} \mathrm{da}^{-1}$, \% 19.99-21.82 ve \% 30.58-35.05 arasında bulunmuştur. Diğer taraftan, interaksiyonlar arasında HP değerleri ise \% 18.89-22.54 arasında değişiklik göstermiştir. Organik gübre uygulamalarının fiğ türlerinin verim ve kalitesi üzerine etkisi sınırlı olmuştur.
Bununla birlikte, hayvan gübresi uygulanan tüylü fiğden $500 \mathrm{~kg} \mathrm{da}^{-1}$ üzerinde kuru ot verimi alınabileceği belirlenmiştir.

Genel Yorum: Elde edilen veriler fiğ türlerinin organik hayvancılıkta ihtiyaç duyulan kaba yemin karşılanmasında önemli bir kaynak olabileceğini ve tüylü fiğin diğer türlerden daha yüksek verime sahip olduğunu göstermiştir. Ayrıca, istatistiksel olarak önemsiz olmakla birlikte Amik Ovası koşullarında hayvan gübresinin fiğ yetiştiriciliğinde zeolit ve leonarditten daha etkili olduğu söylenebilir.

Çalışmanın Önemi ve Etkisi: Organik fiğ yetiştiriciliğinde gübre kullanımı ile ilgili sınırlı sayıda çalışma vardır. Yürütülen araştırma ile organik fiğ tarımı yapan çiftçilere ve ileriki araştırmalara yardımcı olabilecek sonuçlar elde edilmiştir. Ayrıca çalışma sonucunda, kullanılan gübrelerde doz belirleme çalışmalarının yürütülmesi gerektiği sonucuna varılmıştır.

Anahtar Kelimeler: Organik tarım, fiğ türleri, ot verimi, ot kalitesi, organik gübre.

\section{ÇIKAR ÇATIŞMA BEYANI}

Yazar(lar) çalışma konusunda çıkar çatışmasının olmadığını beyan eder.

\section{ARAŞTIRMACILARIN KATKI ORANI BEYAN}

Yazarlar çalışmaya eşit oranda katkı sağlamış olduklarını beyan eder.

\section{KAYNAKLAR}

Açıkgöz E, Çelik N (1986) Bursa kıraç koşullarında bazı önemli tek yıllık baklagil yem bitkilerinin kuru ot verimi ve kalitesi üzerinde ön araştırmalar. U.Ü. Zir. Fak. Derg. 5: 47-53.

Akdeniz H, Koc A, Hossain A, El Sabagh A (2018) Nutritional values of four hairy vetch (Vicia villosa Roth) varieties grown under Mediter environment. Fresenius Environ. Bull. 27(8): 5385-5390.

Akpınar M, Şahin CB, İşler N (2019) Çukurova koşullarında turfanda patates yetiştiriciliğinde farklı azot dozlarının verim ve tarımsal özelliklere etkisi. MKU Tar. Bil. Derg., 24(1): 37-42.

Aksoy i, Nursoy H (2010) Vejetasyonun farklı dönemlerinde biçilen Macar fiği buğday karışımının besin madde kompozisyonu, rumende yıkılım özellikleri, in vitro sindirilebilirlik ve rölatif yem değerinin belirlenmesi. Kafkas Üniv. Vet. Fak. Derg. 16(6): 925-931. 
Anil L, Park J, Phipps RH, Miller FA (1998) Temperate intercropping of cereals for forage: A review of the potential for growth and utilization with particular reference to the UK. Grass Forage Sci. 53(4): 301-317.

Anjum MS, Zammurad Al, Rauf CA (2006) Effect of rhizobium inoculation and nitrogen fertilizer on yield and yield components of mungbean. Int. J. Agric. Biol. 8: 238-240.

Anonim (2017) T.C. Tarım ve Orman Bakanlığı, (2017) Organik tarımla ilgili dokümanlar, Tarım ve Orman Bakanlığı Genel Müdürlüğü, Ankara. https://www.tarimorman.gov.tr/Konular/BitkiselUretim/Organik-Tarim/Istatistikler.

AOAC (1990) Official method of analysis. 15th ed., pp. 66-68. Association of Official Analytical Chemists, Washington, DC, USA.

Atis I, Celiktas N, Can E, Yılmaz S (2019) The effects of cutting intervals and seeding rates on forage yield and quality of alfalfa. Turk. J. Field Crops 24(1): 12-20.

Atis I, Kokten K, Hatipoglu R, Yilmaz S, Atak M, Can E (2012) Plant density and mixture ratio effects on the competition between common vetch and wheat. Aust. J. Crop Sci. 6: 498-505.

Aygün C, Çakal Ş, Kara A (2009) Characterization of some coksfoot (Dactylis glomerata L.) lines from the natural rangelands of Eastern Anatolia. Biological Diversity and Conservation, 2(2):57-64.

Canbolat Ö, Karaman \$̧ (2009) Bazı baklagil kaba yemlerinin in vitro gaz üretimi, organik madde sindirimi, nispi yem değeri ve metabolik enerji içeriklerinin karşılaştırılması. Tar. Bil. Derg. 15(2): 188-195.

Çaçan E, Kökten K, Kaplan M, Yılmaz HŞ (2018) Bazı adi fiğ hat ve çeşitlerinin (Vicia sativa L.) ot verimi ve ot kalitesi açısından değerlendirilmesi. Harran Tar. ve Gida Bil. Derg. 22(1): 47-61.

Demiryürek K (2004) Dünya ve Türkiye'de organik tarım. Harran Üniv. Zir. Fak. Derg. 8(3-4): 63-71.

Demiryürek K (2011) Organik tarım kavramı ve organik tarımın Dünya ve Türkiye'deki durumu. Gaziosmanpaşa Üniv. Zir. Fak. Derg. 28(1): 27-36.

Ece A, Saltalı K, Eryigit N, Uysal F, (2007) The effects of leonardite applications on climbing bean (Phaseolus vulgaris L.) yield and the some soil properties. J. Agron. 6(3): 480-483.

Erol A, Anlarsal AE (2019) Kahramanmaraş koşullarında bazı tek yıllık baklagil yem bitkisi türlerinin arpa ile farklı oranlardaki karışımlarının ot ve tohum verimi ile bazı özelliklere etkisi. International Asian Congress on Contemporary Sciences April 15-24, 2019 Mecca, Saudi Arabia, ss 234-243.
Erol A, Kaplan M, Kızılşimşek M (2009) Oats (Avena sativa) - common vetch (Vicia sativa) mixtures grown on a low-input basis for a sustainable agriculture. Trop. Grassl. 43: 191-196.

Ertekin I, Atış I, Yılmaz Ş, Can E, Kızılşimşek M (2019) Comparison of shrub leaves in terms of chemical composition and nutritive value. KSU J. Agric. Nat. 22(5): 781-786.

Ertekin I, Çakmakçı S (2020) Effect of different rates of bacteria (Rhizobium leguminosarum) inoculated in seed on yield and some quality parameters of common vetch (Vicia sativa L.). KSU J. Agric. Nat. 23(2): 343-348.

Ertekin i, Kızılşimşek M (2020) Effects of lactic acid bacteria inoculation in pre-harvesting period on fermentation and feed quality properties of alfalfa silage. Asian Austral. J. Anim. Sci. 33(2): 245-253.

Ertekin I, Yılmaz Ş, Atak M, Can E (2018). Effects of different salt concentrations on the germination properties of Hungarian vetch cultivars. Turk. J. Agric. and Nat. Sci., 5(2): 175-179.

Ertekin I, Yılmaz Ş, Atak M, Can E, Çeliktaş N (2017) Tuz stresinin bazı yaygın fiğ (Vicia sativa L.) çeşitlerinin çimlenmesi üzerine etkileri. MKÜ Zir. Fak. Derg., 22(2):10-18.

Gül İ, Dumlu Gül Z, Tan M (2015) Yerli fiğ (Vicia sativa L.)'de kimyasal gübre, ahır gübresi ve bazı toprak düzenleyicilerin ot ve tohum verimine etkileri. Iğdır Üniv. Fen Bil. Enst. Derg. 5(1): 65-72.

Gülümser E, Acar Z (2017) Biçim zamanı ve tohum oranlarının Macar fiği tahıl karışımlarının bazı kalite özellikleri üzerine etkisi. Selçuk Tar. ve Gıda Bil. Derg. 31(2): 14-21.

Güzeloğulları E, Albayrak S (2016) Isparta ekolojik koşullarında farklı ekim ve hasat zamanlarının bazı fiğ (Vicia spp.) türlerinin ot verim ve kalitesi üzerine etkileri. Tarla Bit. Mer. Araş. Enst. Derg. 25(2): 158165.

Haj-Ayed M, Gonzalez J, Caballero R, Remedios-Alvir M (2001) Effects of maturity on nutritive value of fieldcured hays from common vetch and hairy vetch. Anim. Res. 50(1): 31-42.

Işıldar AA (1999) Effect of the addition of zeolite to the soil on nitrification. Turk. J. of Agric. and For. 23: 363368.,

Kaplan M, Kokten K, Ozdemir S (2019) Variation in hay yield and quality of Hungarian vetch (Vicia pannonica Crantz) genotypes. Cur. Trends in Nat. Sci. 8(16): 205211. 
Karakurt (E 2000) Bazı buğdaygil yem bitkilerinde azotlu gübre dozlarının önemli tarımsal karakterler üzerine etkileri. Doktora Tezi, Ankara Üniversitesi, Fen Bil, Ens, Tarla Bitkileri ABD, $138 \mathrm{~s}$.

Kendir H (1999) Determination of some yield components of winter vetch species (Vicia spp.) grown in Ankara cond. Tar. Bil. Derg. 5(2): 85-91.

Keppler F, Hamilton JTG, Braß M, Röckmann T (2006) Methane emissions from terrestrial plants under aerobic conditions. Nat. 439: 187-1941.

Kokten K, Toklu F, Atis I, Hatipoglu R (2009) Effects of seeding rate on forage yield and quality of vetch (Vicia sativa L.)-triticale (Triticosecale Wittm.) mixtures under east mediterranean rainfed conditions. African J. of Biotech. 8(20): 5367-5372.

Kolsarıcı Ö, Kaya DM, Day S, İpek A, Uranbey S (2005) Effects of humic acid doses on emergence and seeding growth of sunflower (Helianthus annuus L.). J. of Akdeniz Univ. Fac. of Agric.18 (2): 151-155.

Lithourgidis AS, Vasilakoglou IB, Dhima KV, Dordas CA, Yiakoulaki MD (2006) Forage yield and quality of common vetch mixtures with oat and triticale in two seeding ratios. Field Crops Res. 99: 106-113.

Marten GC, Buxton DR, Barnes RF (1988) Feeding value (forage quality). P. 463-492. In Hanson et al. (eds.) Alfalfa and alfalfa improvement. Agronomy monograph no. 29. ASA-CSSA-SSSA, Madison, Wisconsin, USA, p: 463-492.

Mert M (2017) Organik olarak yetiştirilen pamuk çeşitlerinin azot gereksinimlerinin belirlenmesi. MKU Zir. Fak. Derg., 22(2): 19-34.

Naser M, Bayaz A, Ramin S, Alireza A, Abolfazı A, Mehdi M (2011) Determining nutritive value of soybean straw for ruminants using nylon bags technique. Pakistan J. of Nut. 10: 838-841.

Özyiğit Y, Bilgen M (2006) Bazı baklagil yem bitkilerinde farklı biçim dönemlerinin bazı kalite faktörleri üzerine etkisi. Akdeniz Üniv. Zir. Fak. Derg. 19(1): 29-34.

Parlakay O, Çelik A, Kızıltuğ T (2015) Hatay ilinde tarımsal üretimden kaynaklanan çevre sorunları ve çözüm önerileri. MKU Zir. Fak. Derg., 20(2): 17-26.

Pertuit AJ, Jerry J, Dudley B, Toler JE (2001) Leonardite and fertilizer levels influence tomato seedling growth. Hortsci. 36(5): 913-915.

Rohweder DA, Barnes RE, Jorgensen N (1978) Proposed hay grading standards based on laboratory analysis for evaluating quality. J. of Anim. Sci. 47: 747-759.

Rotar I, Pacurar F, Vidican R, Sima N (2003) Effects of manure/sawdust fertilization on Festuca rubra type meadows at Ghetari (Apuseni Mountains). Grassland Sci. in Europe, 8: 192-197.
Sevimay CS, Kendir H (1996) Ankara koşullarında kışlık yetiştirilen fiğ çeşitlerinin yem verimleri. Türkiye 3 . Çayır-Mera ve Yem Bitkileri Kongresi, 17-19 Haziran, Erzurum. ss 472-478.

Sridhar M, Senani S (2011) Lignin in lignocellulosics-a boon or a bane for ruminants. Everyman's Sci. 66: 227-232.

Şılbır Y, Tansı V, Sağlamtimur T (1991) GAP bölgesinde kışlık ara ürün tarımı ve bölge için önemi. Türkiye 2 . Çayır-Mera ve Yem Bitkileri Kongresi, 28-31 Mayıs, İzmir, ss 292-303,

Tosun M, Altınbaş M, Soya H (1991) Bazı fiğ (Vicia spp.) türlerinde yeşil ot ve dane verimi ile kimi agronomik özellikler arasındaki ilişkiler. Türkiye 2. Çayır-Mera ve Yem Bitkileri Kong, 28-31.Mayıs, İzmir, ss 574-583.

Turna Ç, Ertuş MM (2017) Bazı fiğ çeşitlerinde farklı ekim zamanlarının ot verimine etkisi. 3. Uluslararası Tarım ve Çevre Kongresi, 16-20 Kasım, Antalya, ss 132-138.

Türk M, Bayram G, Budaklı E, Çelik N (2003) A study on effects of different mixtures of zeolite with soil rates on the root and stem growth of alfalfa (Medicago sativa L.). $5^{\text {th }}$ National Field Crop Congress, October 13-17, Diyarbakır,Turkey, pp 564-567.

Van Dyke NJ, Anderson PM (2002) Interpreting a forage analysis. Alabama Cooperative Extension, Circular ANR-890.

Van Soest PJ, Robertson JB, Lewis BA (1991) Methods for dietary fiber, neutral detergent fiber, and non-starch polysaccharides in relation to animal nutrition. J. of Dairy Sci. 74 (10): 3583-3597.

Yavuz M. (2005) Determination of some ruminant feeds' relative feed value and in vitro digestion values. Gaziosmanpaşa Üniv. Zir. Fak. Derg. 22: 97-101.

Yetim S (1999) Faklı miktardaki azot ve humik asitin fasulye bitkisinin ürün miktarı ile azot alımı ve protein içeriği üzerine etkileri. Yüksek Lisans Tezi, Ankara Üniversitesi, Fen Bil. Ens., Tarla Bitkileri ABD, 69 s.

Yılmaz Ş, Günel E, Sağlamtimur T (1996) Amik ovası ekolojik koşullarında yetiştirilebilecek uygun fiğ (Vicia spp.) türlerinin saptanması üzerinde bir araştırma. Türkiye 3. Çayır-Mera ve Yem bitkileri Kongresi, 17-19 Haziran, Erzurum, ss 627-631.

Yılmaz Ş, Hür N, Ertekin i (2018) Seçilmiş bazı köpekdişi ayrığı (Cynodon dactylon (L.) Pers. var. Dactylon) hatlarında ot verimi ve kalitesinin belirlenmesi. Mustafa Kemal Üniv. Zir. Fak. Derg. 23(2): 232-241.

Yolcu H (2010) İlkbahar son donlarının etkili olduğu koşullarda bazı organik ve kimyasal gübrelerin adi fiğin verim ve morfolojik özellikleri üzerine etkileri. Türkiye IV. Organik Tarım Sempozyumu, 28 Haziran-1 Temmuz, Erzurum, ss 535-538. 
Yolcu H (2011) The effects of some organic and chemical fertilizer applications on yield, morphology, quality and mineral content of common vetch (Vicia sativa L.). Turk J. of Field Crops, 16(2): 197-202.

Yolcu H, Polat M, Aksakal V (2009) Morphologic, yield and quality parameters of some annual forages as sole crops and intercropping mixtures in dry conditions for livestock. J. of Food, Agric. and Environ. 7(3-4): 594-599.
Yücel C, Yücel D, Akkaya MR, Anlarsal AE (2014) Bazı ümitvar yaygın fiğ (Vicia sativa L.) genotiplerinde kalite özellikleri. KSU Doğa Bil. Derg. 17(1): 8-14.

Zeybek A (2010) Bazı fiğ türlerine ait çeşitlerin Tekirdağ şartlarında verim ve tarımsal özelliklerinin belirlenmesi. Yüksek Lisans Tezi, Selçuk Üniversitesi, Fen Bil. Ens., Tarla Bitkileri ABD, $44 \mathrm{~s}$. 